\title{
Pemberdayaan perempuan dalam penanggulangan kekerasan dalam rumah tangga di ibu-ibu Pemberdayaan Kesejahteraan Keluarga (PKK) RT 01/ RW 09 Kelurahan Air Putih Kecamatan Tampan Kota Pekanbaru
}

\author{
Emilda Firdaus, \& Sukamarriko Andrikasmi* \\ Fakultas Hukum, Universitas Riau \\ * kreasiimuda@gmail.com
}

\begin{abstract}
Abstrak. Kekerasan dalam rumah tangga adalah suatu bentuk tindakan pelanggaran hak asasi manusia terutama terhadap perempuan yang selalu menjadi korban. Pemerintah telah mengeluarkan regulasi yaitu Undang-undang Nomor 23 Tahun 2004 tentang Penghapusan Kekerasan Dalam Rumah Tangga. Namun kekerasan dalam rumah tangga terus berlansung. Data dari Komnas Perempuan menunjukan grafik kekerasan terhadap perempuan khususnya KDRT semakin meningkat setiap tahunnya. Begitu juga kasus KDRT di Kota Pekanbaru Provinsi Riau menunjukan data yang cukup tinggi. Untuk itu diperlukan pemahaman dan pelatihan tentang peraturan perundang-undangan yang terkait dengan KDRT. Tujuan dari kegiatan pengabdian pada masyarakat ini adalah mendukung program perguruan tinggi melalui pusat studi wanita melakukan perlindungan terhadap hak-hak perempuan. Disamping itu juga untuk menyebarluaskan informasi kepada masyarakat untuk mencegah KDRT. Metode yang digunakan dalam pengabdian pada masyarakat ini adalah ceramah, dialog dan pemecahan kasus-kasus KDRT, gabungan dari metode tersebut diharapkan peserta tidak hanya mendapat materi tentang PKDRT tapi juga terlatih memecahkan berbagai masalah KDRT. Peserta kegiatan ini adalah ibu-ibu PKK RT 01/RW 09 Kelurahan Air Putih Kota Pekanbaru sejumlah 50 orang, dengan pertimbangan bahwa sebagai pengurus dan anggota PKK, dapat mentransfer pengetahuannya kepada ibu-ibu dilingkungan tempat tinggalnya.
\end{abstract}

Kata kunci: pemberdayaan perempuan; penanggulangan; kekerasan dalam rumah tangga; ibu PKK; pekanbaru

\begin{abstract}
Domestic violence is a form of human rights violation especially against women who are always victims. The government has issued a regulation namely Law Number 23 of 2004 concerning the Elimination of Domestic Violence. But domestic violence continues. Data from the National Commission on Violence Against Women shows graphs of violence against women especially domestic violence is increasing every year. Likewise, the case of domestic violence in Pekanbaru City, Riau Province, shows quite high data. For this reason, understanding and training regarding legislation related to domestic violence is needed. The purpose of community service activities is to support higher education programs through women's studies centers to protect women's rights. Besides that it is also to disseminate information to the public to prevent domestic violence. The method used in community service is lectures, dialogues and solving domestic violence cases, a combination of these methods is expected not only to get participants material about PKDRT but also trained to solve various problems of domestic violence. Participants in this activity are 50 PKK RT 01 / RW 09 Air Putih Village Pekanbaru City residents, with the consideration that as PKK administrators and members, they can transfer their knowledge to mothers in their neighborhood.
\end{abstract}

Keywords: women's empowerment; countermeasures; domestic violence; mother PKK; pekanbaru

To cite this article: Firdaus, E., \& S. Andrikasmi. 2019. Pemberdayaan perempuan dalam penanggulangan kekerasan dalam rumah tangga di ibu-ibu Pemberdayaan Kesejahteraan Keluarga (PKK) RT 01/RW 09 Kelurahan Air Putih Kecamatan Tampan Kota Pekanbaru. Unri Conference Series: Community Engagement 1: 598-605 https://doi.org/10.31258/unricsce.1.598-605

(C) 2019 Authors

Peer-review under responsibility of the organizing committee of Seminar Nasional Pemberdayaan Masyarakat 2019 


\section{PENDAHULUAN}

Rumah tangga, sebagai wadah yang telah menjadi tujuan bagi setiap manusia yang ingin melanjutkan dan membahagiakan hidupnya, sehingga dengan demikian keberadaan rumah tangga sangat penting, agar apa yang diharapkan oleh mereka yang menjalaninya dapat terwujud. Hidup berumah tangga tidak akan terlepas dari pertemuan antara laki-laki dan perempuan, dua orang yang berbeda latar belakang, berbeda kebiasaan, namun akan menyatukan tujuan.

Memperhatikan tujuan seseorang yang ingin membentuk suatu rumah tangga, seakan menjadi tidak pantas jika dalam menjalani rumah tangga ada terjadi kekerasan, pencurian, dan bahkan pemerkosaan. Kekerasan dalam rumah tangga merupakan suatu masalah yang sering terjadi dalam kehidupan sehari-hari, adapun perempuan lebih banyak yang menjadi sasaran tersebut jika dibandingkan dengan yang laki-laki.

Kekerasan terhadap perempuan adalah merupakan kejahatan kemanusiaan karena selain melanggar hak asasi manusia juga menimbulkan dampak yang sangat besar baik bagi keluragnya, bagi kelangsungan kehidupan perempuan itu sendiri dan juga bagi masa depan generasi penerus bangsa, karena perempuan merupakan salah satu aset bangsa. Perempuan adalah tiang negara, jika perempuan baik maka baiklah negara tersebut, namun jika perempuannya rusak maka hancurlah negara tersebut, karena dari rahim seorang perempuanlah akan lahir generasi-generasi penerus bangsa.

Undang-Undang Dasar Negara Republik Indonesia Tahun 1945, sebagai hukum dasar adalah konstitusi yang berlaku bagi semua warga negara Indonesia tanpa membedakan suku dan agama. Setiap warga negara dilindungi hak-haknya dan mempunyai kewajiban yang sama. Hak untuk hidup, hak untuk tidak disiksa, hak untuk berkeluarga, hak persamaan didepan hukum dan lain sebagainya, merupakan hak setiap warga negara.

Provinsi Riau, merupakan salah satu provinsi yang sangat strategis dan memiliki cukup banyak potensi sumber daya alam, seperti pertambangan, pertanian dan perikanan. Namun akhir-akhir ini Riau kembali disoroti oleh peristiwa-peristiwa yang berkaitan dengan kekerasan dalam rumah tangga, hal ini dapat terlihat dari data P2TP2A Provinsi Riau, tahun 2018 ada 49 kasus KDRT, dengan rincian 40 kasus ada di Pekanbaru , dan sisanya 9 kasus ada di Kampar dan Rokan Hilir, selanjutnya pada kasus lain ada 412 kasus Pegawai Negeri Sipil di akhir 2018 yang mengakhiri rumah tangga dengan dominasi sang istri atau biasa disebut dengan istilah cerai gugat, dari total 412 kasus perceraian di Pengadilan Tinggi Agama Pekanbaru 288 istrinya yang mengajukan (tribunpekanbaru.com, 24 Juni 2019)

Kekerasan terhadap perempuan dikarenakan jenis kelaminnya perempuan merupakan fenomena yang semakin mengkhawatirkan beberapa dekade ini. Perempuan sebagai salah satu kelompok rentan pelanggaran hak asasi manusia, seringkali menjadi korban kekerasan. Model kekerasan terhadap perempuan juga semakin berkembang baik tipe maupun pelakunya.

Fakta yang terjadi di Indonesia, tingkat kekerasan terhadap perempuan dalam rumah tangga semakin meningkat setiap tahunnya, ternyata produk hukum yang melarang tindak kekerasan terhadap perempuan dalam rumah tangga kalah kuat dengan budaya hukum yang selama ini dianut oleh masyarakat. Persepsi bahwa urusan rumah tangga adalah wilayah pribadi dan merupakan aib jika diketahui oleh orang lain merupakan salah satu faktor yang menyuburkan kasus kekerasan dalam rumah tangga.

Perilaku kekerasan dapat terjadi dalam setiap rumah tangga. Sehingga KDRT bukan terletak pada apa kriterianya, tetapi lebih pada alasan mengapa perilaku kekerasan itu dapat menerpa tiap keluarga (Missa,12). Menurut Susi (2017:1) "Salah satu sumber KDRT yang terjadi di Kabupaten Kampar didasarkan pada beberapa alasan seperti:"

1. Faktor ekonomi

2. Faktor perbedaan fisik, tenaga, dan kekuasaan.

Terjadinya kekerasan terhadap istri berhubungan dengan kekuasaan suami/istri dan diskriminasi gender di masyarakat. Dalam masyarakat, suami memiliki otoritas, memiliki pengaruh terhadap istri dan anggota keluarga yang lain, suami juga berperan sebagai pembuat keputusan. Pembedaan peran dan posisi antara suami dan istri dalam masyarakat diturunkan secara kultural pada setiap generasi, bahkan diyakini sebagai ketentuan agama. Hal ini mengakibatkan suami ditempatkan sebagai orang yang memiliki kekuasaan yang lebih tinggi daripada istri.

Menurut Hans Kelsen, hukum adalah suatu tata perbuatan manusia. Tata perbuatan mengandung arti suatu aturan. Hukum adalah seperangkat peraturan yang dipahami dalam suatu kesatuan yang sistemik. Tidak mungkin untuk memahami hakikat hukum hanya dengan memperhatikan satu peraturan saja. Untuk 
memahami hukum harus dimulai dari perbuatan manusia, karena hukum diciptakan oleh manusia, yang berupa peraturan-peraturan hukum (Kelsen, 2007).

Selanjutnya rumusan masalah adalah Pemberdayaan Perempuan dalam Penanggulangan Kekerasan dalam Rumah Tangga Di Ibu-Ibu Pemberdayaan Kesejahteraan Keluarga (PKK) RT 01/ RW 09 Keluarahan Air Putih Kecamatan Tampan Kota Pekanbaru, tujuan kegiatan umum kegiatan ini adalah untuk menerangkan kepada masyarakat, dengan memberikan pelatihan khususnya bagi ibu-ibu Pemberdayaan Kesejahteraam Keluarga (PKK) RT 01/ RW 09 Kelurahan Air Putih Kecamatan Tampan Kota Pekanbaru dapat mencegah terjadinya Kekerasan dalam rumah tangga, sedangkan tujuan khususnya adalah memberikan pembimbingan secara nyata dan langsung kepada masyarakat agar terciptanya masyarakat yang sadar hukum terutama mengenai Kekerasan dalam rumah tangga di ibu-ibu Pemberdayaan Kesejahteraam Keluarga (PKK) RT 01/ RW 09 Kelurahan Air Putih Kecamatan Tampan Kota Pekanbaru.

Kemudian manfaat kegiatan ini diharapkan kepada Peserta/ mitra adalah mengetahui bagaimana jenis-jenis kekerasan dan pengertian/perlindungan hukum serta dampak kekerasan dalam rumah tangga pada ibu-ibu Pemberdayaan Kesejahteraan Keluarga (PKK) RT 01/ RW 09 Kelurahan Air Putih Kecamatan Tampan Kota Pekanbaru, untuk tim pelaksana adalah merupakan salah satu bagian dari Tri Dharma Perguruan Tinggi yaitu tugas pengabdian kepada masyarakat, dan untuk perguruan pinggi adalah dengan adanya kegiatan ini Universitas Riau akan lebih dikenal kiprahnya dalam menyelesaikan polemik dalam masyarakat secara berkesinambungan dan terarah.

\section{METODE PENERAPAN}

Adapun metode penerapan dalam pelaksanaan kegiatan ini adalah pada masyarakat yang menjadi sasarannya, yaitu melakukan sosialisasi, pelatihan, dan pemberdayaan ibu-ibu Pemberdayaan Kesejahteraan Keluarga (PKK) RT 01/ RW 09 Kelurahan Air Putih Kecamatan Tampan Kota Pekanbaru.

\section{HASIL DAN KETERCAPAIAN SASARAN}

Kekerasan dalam Kamus Besar Bahasa Indonesia berarti: "Perihal yang bersifat, berciri keras; Perbuatan seseorang atau sekelompok orang yang menyebabkan cidera atau matinya orang lain atau menyebabkan kerusakan fisik atau barang orang lain; paksaan (KBBI, 2003).

Galtung menguraikan ada enam dimensi penting dari kekerasan yaitu sebagai berikut (Windu, 1992):

1. Kekerasan fisik dan psikologis. Dalam kekerasan fisik, tubuh manusia disakiti secara jasmani bahkan sampai pada pembunuhan. Sedangkan kekerasan psikologis adalah tekanan yang dimaksudkan meredusir kemampuan mental atau otak.

2. Pengaruh positif dan negatif. Sistem orientasi imbalan (reward oriented) yang sebenarnya terdapat "pengendalian", tidak bebas, kurang terbuka, dan cenderung manipulatif, meskipun memberikan kenikmatan dan euphoria.

3. Ada objek atau tidak. Dalam tindakan tertentu tetap ada ancaman kekerasan fisik dan psikologis, meskipun tidak memakan korban tetapi membatasi tindakan manusia.

4. Ada subjek atau tidak. Kekerasan disebut langsung atau personal jika ada pelakunya, dan apabila tidak ada pelakunya disebut struktural atau tidak langsung. Kekerasan tidak langsung sudah menjadi bagian struktur itu (strukturnya jelek) dan menampakkan diri sebagai kekuasaan yang tidak seimbang yang menyebabkan peluang hidup tidak sama.

5. Disengaja atau tidak. Bertitik berat pada akibat dan bukan tujuan, pemahaman yang hanya menekankan unsur sengaja tentu tidak cukup untuk melihat, mengatasi kekerasan struktural yang bekerja secara halus dan tidak sengaja. Dari sudut korban, sengaja atau tidak sengaja, kekerasan tetap kekerasan.

6. Yang tampak dan tersembunyi. Kekerasan yang tampak, nyata (manifest), baik yang personal maupun struktural, dapat dilihat meski secara tidak langsung. Sedangkan kekerasan tersembunyi adalah sesuatu yang memang tidak kelihatan (latent), tetapi bisa dengan mudah meledak. Kekerasan tersembunyi akan terjadi jika situasi menjadi begitu tidak stabil sehingga tingkat realisasi aktual dapat menurun dengan mudah. Kekerasan tersembunyi yang struktural terjadi jika suatu struktur egaliter dapat dengan mudah diubah menjadi feodal, atau evolusi hasil dukungan militer yang hirarkis dapat berubah lagi menjadi struktur hirarkis setelah tantangan utama terlewati. 
Kekerasan yang disebabkan oleh bias gender disebut juga dengan gender related violence yang mempunyai macam dan bentuk kejahatan, diantaranya:

1. Bentuk pemerkosaan terhadap perempuan, termasuk pemerkosaan didalam perkawinan. Perkosaan terjadi jika seseorang melakukan paksaan untuk mendapatkan pelayanan seksual tanpa kerelaan yang bersangkutan. Ketidak relaan ini sering kali tidak bisa diungkapkan karena berbagai faktor, misalnya rasa malu, ketakutan, ataupun keterpaksaan, baik ekonomi maupun kultural;

2. Tindakan pemukulan dan serangan fisik yang terjadi di rumah tangga atau domestic violence, termasuk tindak kekerasan dalam bentuk penyiksaan terhadap anak-anak atau child abuse;

3. Bentuk penyiksaan yang mengarah kepada organ alat kelamin atau genital multilation misalnya, penyunatan terhadap anak perempuan;

4. Kekerasan dalam bentuk pelacuran atau prostitution. Pelacuran merupakan bentuk kekerasan terhadap perempuan yang diselenggarakan oleh suatu mekanisme ekonomi yang merugikan kaum perempuan. Setiap Negara dan masyarakat selalu menggunakan standar ganda terhadap pekerja seksual ini. Di satu sisi, Pemerintah melarang dan menangkap mereka, tetapi di sisi lain Negara juga menarik pajak dari mereka. Selain itu, masyarakat selalu memandang rendah pelacur sebagai sampah masyarakat sementara tempat kegiatan mereka selalu ramai dikunjungi orang, terutama laki-laki;

5. Kekerasan dalam bentuk pornografi. Pornografi termasuk kekerasan non fisik berupa pelecehan terhadap kaum perempuan karena tubuh perempuan dijadikan obyek demi keuntungan seseorang;

6. Kekerasan dalam bentuk pemaksaan sterillisasi dalam keluarga berencana atau enforced sterilization. Keluarga berencana dibanyak tempat ternyata telah menjadi sumber kekerasan terhadap perempuan. Dalam rangka memenuhi target mengontrol pertumbuhan penduduk, perempuan sering kali dijadikan korban demi program tersebut meskipun semua orang tahu bahwa persoalannya tidak saja pada perempuan, tetapi juga berasal dari kaum laki-laki;

7. Kekerasan terselubung atau molestation berupa memegang atau menyentuh bagian tertentu dari tubuh perempuan dengan berbagai cara dan kesempatan tanpa kerelaan si pemilik tubuh. Jenis kekerasan ini sering terjadi ditempat pekerjaan ataupun ditempat umum;

8. Tindakan kejahatan terhadap perempuan yang paling umum dilakukan masyarakat adalah pelecehan seksual. Banyak orang membela bahwa pelecehan seksual sangat relatif karena sering tindakan tersebut merupakan usaha untuk bersahabat tetapi sesungguhnya pelecehan seksual bukanlah usaha untuk bersahabat karena tindakan tersebut merupakan hal yang tidak menyenangkan bagi perempuan (Rika, 2009).

\section{Tindak kekerasan sebagai diskriminasi terhadap perempuan}

Pasal 1 Konvensi Wanita menentukan arti diskriminasi terhadap perempuan sebagai (Achie, 2000):

a. Setiap pembedaan, pengucilan atau pembatasan,

b. Yang dibuat atas perbedaan jenis kelamin

c. Yang mempunyai pengaruh atau tujuan untuk mengurangi atau menghapuskan

d. Pengakuan, penikmatan atau penggunaan hak asasi manusia dan kebebasan-kebebasan pokok,

e. Dibidang politik, ekonomi, sosial, budaya, sipil atau apa pun lainnya oleh wanita

f. Terlepas dari status perkawinan mereka

g. Atas dasar persamaan antara pria dan wanita

Defenisi kekerasan dan arti kekerasan terhadap perempuan belum dicantumkan dalam Konvensi Wanita (CEDAW). Penjelasan tentang kekerasan terhadap perempuan dicantumkan dalam Rekomendasi Umum Komite CEDAW No.19 Tentang Kekerasan Terhadap Perempuan.

Dalam latar belakang dari terbitnya Rekomendasi Umum Nomor 19 Tentang Kekerasan terhadap Perempuan dinyatakan antara lain bahwa (Achie, 2000):

a. Kekerasan berbasis gender adalah suatu bentuk diskriminasi yang secara serius menghalangi kesempatan perempuan untuk menikmati hak dan kebebasannya atas dasar persamaan antara laki-laki dan perempuan.

b. Dalam tahun 1989, Komite merekomendasikan bahwa Negara peserta harus memasukkan dalam laporannya informasi mengenai kekerasan dan langkah-langkah tindak untuk menanggulanginya (Rekomendasi Umum No.12, Sidang ke-8).

c. Pada Sidang ke-10 tahun 1991, dialokasikan bagian dari sidang ke-10 untuk suatu diskusi dan kajian atas Pasal 6 dan pasal-pasal lain dari Konvensi yang ada hubungannya dengan kekerasan terhadap perempuan, pelecehan seksual, dan eksploitasi terhadap perempuan. Pokok masalah tersebut dipilih 
untuk mengantisipasi diselenggarakannya Konferensi Dunia Tentang Hak Asasi Manusia (HAM) di Wina tahun 1993.

Rekomendasi Nomor 19, sidang ke 11 Komite, 1992, tentang kekerasan terhadap wanita. Komite menyarankan kepada negara-negara peserta bahwa dalam melakukan tinjauan mengenai peraturan perundangundangan dan kebijaksanaan, dan dalam menyampaikan laporan pelaksanaan Konvensi, perlu diperhatikan pendapat Komite mengenai kekerasan berdasarkan perbedaan jenis kelamin, sebagai berikut (Achie, 1992) :

a. Pasal 1 Konvensi menerapkan defenisi mengenai diskriminasi. Defenisi mengenai diskriminasi meliputi kekerasan berdasarkan jenis kelamin, yaitu kekerasan yang ditujukan kepada wanita, karena ia adalah seorang wanita atau mempunyai pengaruh secara tidak sepadan pada wanita. Kekerasan itu meliputi tindakan yang mengakibatkan kerusakan atau penderitaan fisik, mental atau seksual, ancaman tindakan tertentu, pemaksaan atau perampasan kemerdekaan. Kekerasan berdasarkan jenis kelamin melanggar ketentuan-ketentuan tertentu dari Konvensi, walaupun kata kekerasan tersebut tidak disebut dalam ketentuan itu.

b. Kekerasan berdasarkan jenis kelamin, yang mengurangi atau meniadakan penikmatan hak asasi manusia dan kebebasan dasar oleh wanita berdasarkan hukum internasional atau konvensi hak asasi manusia, adalah diskriminasi sesuai dengan arti Pasal 1 Konvensi. Hak-hak dan kebebasan itu meliputi: (a) hak atas kehidupan, (b) hak untuk tidak mengalami penganiayaan atau kekejaman, perlakuan atau penyiksaan secara tidak manusiawi atau merendahkan martabat, (c) hak untuk mendapat perlindungan yang sama berdasarkan norma-norma kemanusiaan pada waktu terjadi konflik bersenjata internasional atau nasional, (d) hak atas kemerdekaan dan keamanan pribadi, (e) hak atas perlindungan yang sama di muka hukum, (f) hak atas persamaan dalam keluarga, (g) hak untuk mendapatkan pelayanan kesehatan fisik dan mental yang sebaik-baiknya, (h) hak atas pekerjaan yang layak dan kondisi kerja yang baik.

c. Konvensi diberlakukan atas kekerasan yang dilakukan oleh pejabat publik. Tindak kekerasan seperti itu dapat melanggar kewajiban negara itu terhadap hukum internasional hak asasi manusia atau konvensi lainnya, serta melanggar Konvensi Wanita.

d. Ditekankan bahwa diskriminasi menurut Konvensi tidak terbatas pada tindakan oleh atau untuk pemerintah (perhatikan Pasal 2(e), 2(f) dan 5). Pasal 2(e) Konvensi, mewajibkan negara peserta untuk melakukan segala upaya yang tepat untuk menghapus diskriminasi terhadap wanita oleh orang, organisasi atau perusahaan. Berdasarkan hukum internasional atau kovenan khusus hak asasi manusia, negara dapat juga dinyatakan bertanggungjawab atas tindakan privat apabila negara itu tidak melakukan tindakan dengan baik untuk mencegah adanya pelanggaran hak atau menyidik dan menghukum, dan menyediakan kompensasi atas tindak kekerasan itu.

\section{Tinjauan umum undang-undang kekerasan dalam rumah tangga}

Rumah tangga seharusnya adalah tempat yang paling aman dan membahagiakan bagi seluruh anggota keluarga. Rumah adalah tempat bercengkrama dan saling berbagi kasih antara penghuninya, namun berbagai perkembangan kehidupan manusia menyebabkan terjadinya perubahan pada berbagai aspek. Perubahanperubahan tersebut ada yang berdampak positif bagi kehidupan sosial manusia dan ada juga yang membawa dampak negatif tergantung bagaimana perubahan tersebut dapat mempengaruhi pola pikir, model interaksi sosial, ekonomi, budaya, hukum dan politik.

Kekerasan dalam rumah tangga adalah suatu bentuk kejahatan yang sudah berlangsung lama dan membudaya dalam masyarakat Indonesia. Kekerasan jenis ini sering disebut dengan hidden crime atau kejahatan yang tersembunyi dan domestic violence atau kekerasan dalam keluarga, karena baik pelaku ataupun korban berusaha untuk merahasiakan perbuatan tersebut dari orang lain atau disebut juga dengan kekerasan dibalik kamar.

Korban kekerasan dalam rumah tangga sangat kesulitan mencari perlindungan atas peristiwa yang menimpanya. Kurangnya instrumen hukum dan nilai budaya yang sudah mengakar bahwa persoalan rumah tangga adalah masalah privat dan merupakan aib jika sampai orang lain tahu merupakan salah satu faktor penghambat implementasi perlindungan hak-hak perempuan korban kekerasan dalam rumah tangga. Persoalan kekerasan dalam rumah tangga ibarat gunung es yang hanya mencuat di permukaan saja, faktanya masih banyak kasus-kasus yang tidak dilaporkan karena berbagai hambatan seperti budaya dan persepsi akan nilainilai agama yang salah.

Ditinjau dari perspektif hukum, pemerintah telah berupaya melindungi kaum perempuan dengan diratifikasinya Konvensi mengenai Penghapusan Segala bentuk Diskriminasi Terhadap Perempuan, yaitu Convention on the Elimination for All Form of Discrimination Against Women melalui UU Nomor 7 tahun 
1984. Artinya secara yuridis Indonesia telah mengikatkan diri untuk melaksanakan ketentuan-ketentuan dalam konvensi wanita tersebut.

Peristiwa pembahasan rancangan undang-undang (selanjutnya disebut RUU) kekerasan dalam rumah tangga dalam rapat paripurna Dewan Perwakilan Rakyat itu bukan peristiwa yang tiba-tiba, akan tetapi merupakan buah perjuangan berbagai kalangan yang peduli dengan masalah kekerasan terhadap perempuan yang tergabung dalam Jangka PKTP atau Jaringan Kerja Advokasi Kebijakan Penghapusan Kekerasan Terhadap Perempuan. Meskipun bermula dari desakan aktivis perempuan, selanjutnya menjadi penting untuk dipahami oleh berbagai kalangan dinegeri ini bahwa Legislasi RUU Anti KDRT merupakan keharusan bagi Indonesia sebagai Negara yang telah meratifikasi beberapa konvensi internasional tentang perempuan dan bukan karena desakan aktivis perempuan (www.duniaesay.com, 2011 ).

Lahirnya Rancangan ini berasal dari inisiatif LBH Advokasi untuk perempuan Indonesia dan keadilan (LBH APIK) bersama dengan Lembaga Swadaya Masyarakat lainnya yang tergabung dalam Jaringan Kerja Advokasi Anti Kekerasan Terhadap Perempuan (Jangka PKTP) untuk menyiapkan RUU anti KDRT. RUU KDRT ini telah disiapkan LBH Apik dan Jaringan PKTP sejak tahun 1998 melalui dialog publik. Persiapan ini memang termasuk lama mengingat isu KDRT masih kurang dikenal dimasyarakat dan diragukan oleh kalangan tertentu. Pada tanggal 30 Juni 2004, Presiden Megawati Soekarno Putri mengirimkan surat penugasan kepada Menteri Negara Pemberdayaan Perempuan untuk membahas RUU Anti Kekerasan dalam Rumah Tangga. Keluarnya surat Presiden RI No.R.14/PU/VI/204 menandai perkembangan rancangan undangundang anti kekerasan yang diajukan Dewan Perwakilan Rakyat sebagai hak inisiatif lembaga tersebut dan disahkan dalam sidang paripurna Badan Musyawarah (Bamus) DPR pada tanggal 13 mei 2003. Setelah menunggu lebih dari 13 bulan, akhirnya Presiden menunjuk kantor Kementrian Pemberdayaan Perempuan sebagai mitra DPR membahas rancangan undang-undang tersebut. RUU KDRT ini mengadopsi berbagai perundangan dari negara seperti Malaysia yang sampai pada kesimpulan KDRT adalah kejahatan. Tentu saja RUU ini disesuaikan dengan kondisi Indonesia. Setelah melalui proses selama satu tahun sejak tahun 2003 hingga tahun 2004, risalah sidang setebal 1321 halaman menghasilkan Undang-undang Nomor 23 Tahun 2004 tentang Penghapusan Kekerasan Dalam Rumah Tangga (UU PKDRT) (Aroma, 2013).

RUU ini berasal dari hak inisiatif DPR RI yang disusun dan diusulkan kepada pimpinan DPR RI. Adapun pengusulan ini didasarkan pada fakta-fakta sebagai berikut (Aroma, 2013): Peningkatan statistik kasus KDRT dalam berbagai bentuknya;

a. Peraturan perundangan yang ada, Kitab Hukum Pidana (KUHP) dan Kitab Hukum Acara Pidana (KUHAP) senyatanya belum dapat menyentuh persoalan kasus-kasus KDRT dan melindungi para korban;

b. Berbagai hambatan yang menyulitkan korban kekerasan dalam rumah tangga dalam mendapatkan akses hukum;

c. RUU tersebut diberitahukan dan dibagikan kepada semua anggota DPR RI melalui rapat Paripurna yang dipimpin oleh Wakil Ketua DPR RI, pada tanggal 27 Januari 2003;

d. Proses selanjutnya adalah tanggapan dari fraksi-fraksi pada rapat paripurna yang kembali dipimpin oleh Wakil Ketua DPR RI, tanggal 13 Mei 2003.

Anggota DPRD dan pemerintah harus memaklumi bahwa Indonesia telah meratifikasi konvensi CEDAW (convention on the Elimitanion of all forms of Discrimation against women) atau konvensi tentang penghapusan segala bentuk diskriminasi terhadap perempuan melalui Undang-Undang Nomor 7 tahun 1984 sebagai konsekuensi dari ratifikasi ini Indonesia harus melakukan :

1. Pembentukan hukum dan atau harmonisasi hukum sesuai kaidah hukum yang terdapat dalam konvensi tersebut. Kewajiban ini dilakukan dengan mengkaji peraturan perundang-undangan atau membuat perundangan baru berdasarkan konvensi yang telah diratifikasi;

2. Penegakan hukum mengenai hak-hak perempuan melalui pengadilan nasional dan lembaga pemerintah lainnya.

CEDAW telah memberikan arti "diskriminasi” secara komprehensif sebagaimana ditentukan dalam Pasal 1 CEDAW bahwa "dalam konvensi ini istilah "diskriminasi terhadap perempuan" berarti setiap pembedaan, pengucilan atau pembatasan yang dibuat atas dasar jenis kelamin yang mempunyai pengaruh atau tujuan untuk mengurangi atau menghapuskan pengakuan, penikmatan atau penggunaan hak asasi manusia dan kebebasankebebasan pokok di bidang politik, ekonomi, sosial, budaya, sipil atau apapun lainnya bagi kaum perempuan, terlepas dari status perkawinan mereka atas dasar persamaan hak laki-laki dan perempuan. 
Unsur-unsur yang terkandung dalam istilah diskriminasi tersebut meliputi :

1. Ideologi, berupa asumsi-asumsi berbasis gender tentang peran dan kemampuan perempuan;

2. Tindakan, pembedaan perlakuan, pembatasan atau pengucilan perempuan;

3. Niat, diskriminasi langsung atau tidak langsung;

4. Akibat;

5. Pengurangan atau penghapusan pengakuan, penikmatan, penggunaan hak dan kebebasan,

6. Diskriminasi dalam semua bidang (politik, ekonomi, sosial, budaya, sipil) dan oleh setiap pelaku (www.djpp.depkumham.go.id, 2011).

Dalam pasal 2 Undang-Undang PKDRT disebutkan bahwa lingkup rumah tangga dalam undang-undang ini meliputi:

1. Lingkup rumah tangga dalam undang-undang ini meliputi:

a. Suami, istri, dan anak;

b. Orang-orang yang mempunyai hubungan keluarga dengan orang sebagaimana dimaksud pada huruf a karena hubungan darah, perkawinan, persusuan, pengasuhan, dan perwalian, yang menetap dalam rumah tangga; dan

c. Orang yang bekerja membantu rumah tangga dan menetap dalam rumah tangga tersebut.

2. Orang yang bekerja sebagaimana dimaksud huruf $\mathrm{C}$ dipandang sebagai anggota keluarga dalam jangka waktu selama berada dalam rumah tangga yang bersangkutan.

Selanjutnya, dalam penjelasan pasal 2 disebutkan bahwa yang dimasud dengan anak adalah termasuk anak angkat dan anak tiri. Kemudian, yang dimaksud dengan hubungan perkawinan, misalnya mertua, menantu, ipar dan besan (Rika, 2009).

Selanjutnya, Pasal 4 Undang-Undang PKDRT mengatur tentang tujuan disusunnya undang-undang tersebut, yaitu:

1. Mencegah segala bentuk kekerasan dalam rumah tangga;

2. Melindungi korban kekerasan dalam rumah tangga;

3. Menindak pelaku kekerasan dalam rumah tangga; dan

4. Memelihara keutuhan rumah tangga yang harmonis dan sejahtera.

Undang-Undang PKDRT berlaku untuk setiap orang yang melakukan perbuatan kekerasan dalam rumah tangga di Indonesia. Pasal 5 menjelaskan tentang larangan kekerasan dalam rumah tangga, yang dilakukan baik secara kekerasan fisik, kekerasan psikis, kekerasan seksual atau penelantaran rumah tangga (UUPKDRT, 2004).

\section{KESIMPULAN}

Pemberdayaan perempuan untuk mencegah terjadinya kekerasan dalam rumah tangga di kalangan Ibu-Ibu PKK RT/ RW 01/09 Kelurahan Air Putih Kecamatan Tampan Kota Pekanbaru, dilaksanakan dengan memberikan pelatihan dan sosialisasi tentang kekerasan dalam rumah tangga dengan menjelaskan tentang bentuk-bentuk kekerasan dalam rumah tangga dan melaksanan sosialisasi tentang kepastian hukum akan perlindungan perempuan. Kemudian kedepannya bentuk ideal yang diberikan kepada peremuan dalam konsep agar tidak menjadi korban kekerasan dalam rumah tangga seharusnya lebih berkesinambungan dan terarah.

\section{DAFTAR PUSTAKA}

Aroma, E. M. 2013. Proses Pembentukan Hukum Kekerasan Terhadap Perempuan di Indonesia dan Malaysia. Yogyakarta. Aswajana Pressindo.

Kelsen, H. 2007. General Theory of Law and State (Teori Umum Hukum dan Negara. Dasar-dasar Ilmu Hukum Normatif Sebagai Ilmu Hukum Deskriptif - Empirik) alih bahasa oleh Somardi. BEE. Jakarta. Media Indonesia.

Marsana, W. I. 1992. Kekuasaan \& Kekerasan Menurut Johan Galtung. Yogyakarta. Kanisius.

Rika, S. 2009. Perempuan dan Penyelesaian Kekerasan Dalam Rumah Tangga. Bandung. PT Citra Aditiya Bhakti.

Departemen Pendidikan Nasional. 2003. Kamus Besar Bahasa Indonesia. Jakarta. PT.Balai Pustaka.

Mudjiati. 2011. Penghapusan Kekerasan Dalam Rumah Tangga Suatu Tantangan Menuju Sistem Hukum Yang Responsif Gender", diakses dari www.djpp.depkumham.go.id diakses pada 17 Desember 2011. 
Nur, H. 2011. Menunggu Lahirnya UU Anti Kekerasan dalam Rumah Tangga. www.duniaesay.com diakses pada 16 Desember 2011.

Riawati, D. 2019. 49 Kasus KDRT Terjadi di Riau, Ada PNS, ini Rincian dan dampaknya terhadap Anak. www.tribunpekanbaru.com Diakses pada 24 Juni 2019. 